\title{
Relationships among Peach, Almond, and Related Species as Detected by Simple Sequence Repeat Markers
}

\author{
P. Martínez-Gómez, S. Arulsekar, D. Potter, and T.M. Gradziel ${ }^{1}$ \\ Department of Pomology, University of California, Davis, CA 95616
}

\begin{abstract}
Additional IndeX words. Prunus spp., cluster analysis, phylogenetic relations, breeding
Abstract. The genetic relationships among peach [Prunus persica (L.) Batsch], almond [P. dulcis (Mill.) D.A. Webb or P. amygdalus (L.) Batsch] and 10 related Prunus species within the subgenus Amygdalus were investigated using simple sequence repeat (SSR) markers. P. glandulosa Pall. was included as an outgroup. Polymorphic alleles were scored as present or absent for each accession. The number of alleles revealed by the SSR analysis in peach and almond cultivars ranged from one to three whereas related Prunus species showed a range of one to 10 alleles. Results demonstrated an extensive genetic variability within this readily intercrossed germplasm as well as the value of SSR markers developed in one species of Prunus for the characterization of related species. Mean character difference distances were calculated for all pairwise comparisons and were used to construct an unrooted dendogram depicting the phenetic relationships among species. Four main groups were distinguished. Peach cultivars clustered with accessions of $P$. davidiana (Carr.) Franch. and $P$. mira Koehne. The second group contained almond cultivars. A third group included accessions of $P$. argentea (Lam) Rehd., P. bucharica Korschinsky, P. kuramica Korschinsky, P. pedunculata Pall, P. petunikowii Lits., P. tangutica (Spach) Batal., and $P$. webbii (Spach) Vieh.. $P$. glandulosa and $P$. scoparia Batal. were included in a fourth group.
\end{abstract}

Peach (Prunus persica) and almond (P. dulcis) syn. (P. amygdalus) are two species of genus Prunus subgenus Amygdalus (Rosaceae, subfamily Prunoideae) that are commercially grown worldwide. These species originated in Southeastern and Central Asia respectively, and represent divergent evolution under two distinct environments, being warmer and more humid in the case of peach, and colder and xerophytic for almond (Watkins, 1976). Related Prunus species are found growing wild from eastern China to the mountainous areas and deserts of western China, Kurdistan, Turkestan, Afghanistan and Iran (Browick and Zohary, 1996; Faust and Timon, 1995; Grasselly, 1976; Hesse, 1975; Kester and Gradziel, 1996; Kester et al., 1991; Scorza and Sherman, 1996).

The direct use of these related Prunus species as a rootstock for peach and almond, mainly under non-irrigated native conditions, has been reported by several authors (Denisov, 1988; Grasselly, 1976; Hesse, 1975). Interspecific crosses (peach X almond, peach X $P$. davidiana, and $P$. webbii $\mathrm{x}$ peach) have also been used as peach and almond rootstocks (Berhnard, 1949; Brooks and Olmo, 1982; Kester and Hansen, 1966). Hesse (1975) and Scorza and Sherman (1996) suggested the value of closely related Prunus species in peach breeding. Related species have also been reported as having potential in almond breeding to improve the quality of kernels and as sources of self-compatibility (Gradziel and Kester, 1998; Gradziel et al., 2001; Kester and Gradziel, 1996; Kester et al., 1991).

Studies of germplasm diversity and genetic relationships can be used to assess the value of these species in cultivar development. Early studies of Prunus involved isozymes (Mowrey and Werner, 1990) and restriction fragment analysis of chloroplast DNA (Badenes and Parfitt, 1995; Uematsu et al., 1991). Recent studies analysed variation in DNA sequences of internal transcribed spacers (ITS) in nuclear ribosomal DNA (Lee and Wen, 2001) and chloroplast DNA (Bortiri et al., 2001). Analysis was from a taxonomic perspective, assaying a wide range of species.

Received for publication 12 Aug. 2002. Accepted for publication 18 Mar. 2003. 1Corresponding author; e-mail tmgradziel@ucdavis.edu.
Simple sequence repeat (SSR) markers (microsatellites) are characterized by high polymorphism and abundance, with codominant inheritance, and are often transferable across closely related species (Gupta et al., 1996). These molecular markers are ideal for assessing genetic variability in related species and understanding the genetic relationships among them (Westman and Kresovich, 1997). Recently, SSR primers generated in different Prunus species have been reported (Aranzana et al., 2002; Cantini et al., 2001; Cipriani et al., 1999; Dirlewanger et al., 2002; Downey and Iezzoni, 2000; Joobeur et al., 2000; Sosinski et al., 2000; Wang et al., 2002 ). These include highly informative markers that are required for accurate estimation of the amount and nature of genetic variability.

The objective of this research was to establish the genetic relationships among peach, almond and 10 related Prunus species using SSR markers, possibly facilitating their use in interspecific introgression and cultivar improvement.

\section{Materials and Methods}

Plant material and DNA isolation. Evaluated germplasm included six peach cultivars (Chinese Cling, Bailey, Fay Elberta, Halford, Siberian C, and Tzim Pee Tao) and five almond cultivars (Ferragnes, Garden Prince, Mission, Ne Plus Ultra and Nonpareil), which are representative of the diversity in these species (Table 1). Two accession of each of 10 related Prunus species within the subgenus Amygdalus (P. argentea, P. bucharica, P. davidiana, $P$. kuramica, P. mira, P. pedunculata, P. petunikowii, P. scoparia, $P$. tangutica, and $P$. webbii) were also included. An accession of $P$. glandulosa was included as an outgroup for statistical analysis (Table 2).

Total genomic DNA was isolated using the procedure described by Gepts and Clegg (1989). DNA was quantified using a fluorometer DyNAQuant 200 (Amershan-Pharmacia, Piscataway, N.J.).

SSR ANALYSIS. Eighteen SSR markers developed in sweet cherry or peach (Table 3) were screened for DNA polymorphism. The primers were synthesized by Gibco-BRL (Gibco BRL, Carlsbad, 
Table 1. Origin, parentage and main agronomic characteristics of the peach and almond cultivars assayed.

\begin{tabular}{lccl}
\hline Cultivar & Origin & Parentage & Main agronomic characteristics \\
\hline Chinese Cling & China & Unknown & Clingstone peach used for processing \\
Bailey & US & Unknown & Freestone peach used as rootstock \\
Fay Elberta & US & Elberta $(\mathrm{OP})^{\mathrm{z}}$ & Freestone peach used for the fresh market \\
Halford & US & Lovell $(\mathrm{OP})^{\mathrm{z}}$ & Cling peach used for processing \\
Siberian C & China & Unknown & Clingstone peach used as rootstock \\
Tzim Pee Tao & China & Unknown & Freestone peach used as rootstock \\
Ferragnes & France & Cristomorto x Ai & Soft-shell and self-incompatible almond \\
Garden Prince & US & Peach x almond & Paper-shell and self-compatible almond \\
Mission & US & Unknown & Semi-hard shell and self-incompatible almond \\
Ne Plus Ultra & US & Unknown & Soft-shell and self-incompatible almond \\
Nonpareil & US & Unknown & Paper-shell and self-incompatible almond \\
\hline
\end{tabular}

${ }_{\mathrm{z}} \mathrm{OP}=$ open pollinated, pollen parent unknown.

Calif.). The PCR reaction was done in $25-\mu \mathrm{L}$ volumes and the reaction mixture contained $10 \mu \mathrm{M}$ Tris- $\mathrm{HCl}(\mathrm{pH} 8.2), 50 \mathrm{~mm}$ $\mathrm{KCl}, 1.9 \mathrm{~mm} \mathrm{MgCl}_{2}, 100 \mu \mathrm{M}$ of each dNTP, $0.125 \mu \mathrm{M}$ of each primer (forward and reverse), one unit of Taq DNA polymerase enzyme (Roche Applied Science. Indianapolis, Ind.), and 50 ng of genomic DNA. The cycling parameters were one cycle of 95 ${ }^{\circ} \mathrm{C}$ for $3 \mathrm{~min}$; 35 cycles of $94{ }^{\circ} \mathrm{C}$ for $1 \mathrm{~min}, 57^{\circ} \mathrm{C}$ for $1 \mathrm{~min}$, and $72{ }^{\circ} \mathrm{C}$ for $2 \mathrm{~min}$; followed by $10 \mathrm{~min}$ at $72{ }^{\circ} \mathrm{C}$. Annealing temperature used $\left(57^{\circ} \mathrm{C}\right)$ is the temperature recommended for these primers in peach (Cipriani et al., 1999; Testolin et al., 2000). In addition, Hormaza, et al. (2002) and Serrano et al. (2002) used a similar temperature of $55^{\circ} \mathrm{C}$ in the application of these pairs of primers in a wide range of Prunus species. The PCR reactions were carried out in a 96-well block Robocycler (Stratagene Inc., La Jolla, Calif.). Amplified PCR products were separated in a 3\% Metaphor (Biowittaker, Rockland, Maine) agarose gel $(1 \times$ TBE buffer), stained with ethidium bromide and photographed. A 123bp ladder (Gibco BRL) was used as a molecular size standard.

Phenetic Relationships. Polymorphic alleles were scored as present or absent. Some primer combinations did not generate any products in some accessions, and we analysed the data with the alleles for those markers scored in two different ways. First, we assigned missing values (?) to all alleles in a particular accession for any marker for which no amplification was observed in that accession. Second, we coded all such alleles as absent (0) in those accessions. Mean character difference distances were calculated for all pairwise comparisons in PAUP* test version 4.0b4a (Swofford, 2000). The results were used to construct an unrooted dendrogram using the neighbor-joining (NJ) algorithm
(Saitou and Nei, 1987) that depicts the phenetic relationships among the different accessions.

\section{Results}

Polymorphism. The number of alleles revealed by the SSR analysis in peach and almond cultivars ranged from one to three (data not shown), whereas all the other Prunus species showed a range from one to ten alleles for the different markers assayed. UDP96-003 was the most polymorphic marker with a total of 10 alleles detected in the different Prunus species assayed. The SSR markers UDP96-010 and UDP96-015 were specific for peach $(P$. persica) (Table 3 ).

Amplification was successful for all 18 SSR loci assayed in peach, with 15 of the loci successful in almond (P. dulcis). For other species, the number of loci that amplified ranged from 16 in P. davidiana, 15 in P. mira and P. webbii, to 6 in P. glandulosa (Table 4).

A total of 42 and 48 polymorphic bands were scored for the six peach and five almond cultivars, respectively. For the remaining Prunus species, polymorphism was evaluated from only two accessions, and so were reduced in number. Nevertheless, it was possible to see differences among species. Prunus argentea, $P$. bucharica, $P$. davidiana, $P$. kuramica, $P$. mira, and $P$. webbii had more than 20 polymorphic bands. A range of 10 to 16 polymorphic bands was observed in $P$. glandulosa, P. pedunculata, $P$. petunikowii, P. scoparia, and P. tangutica (Table 4).

Phenetic Relationships. Phenetic relationships among the peach and almond cultivars and related species, based on the second

Table 2. Species from the genus Prunus subgenus Amygdalus assayed and their potential use in peach and almond breeding, with P. glandulosa of the subgenus Cerasus as an outgroup.

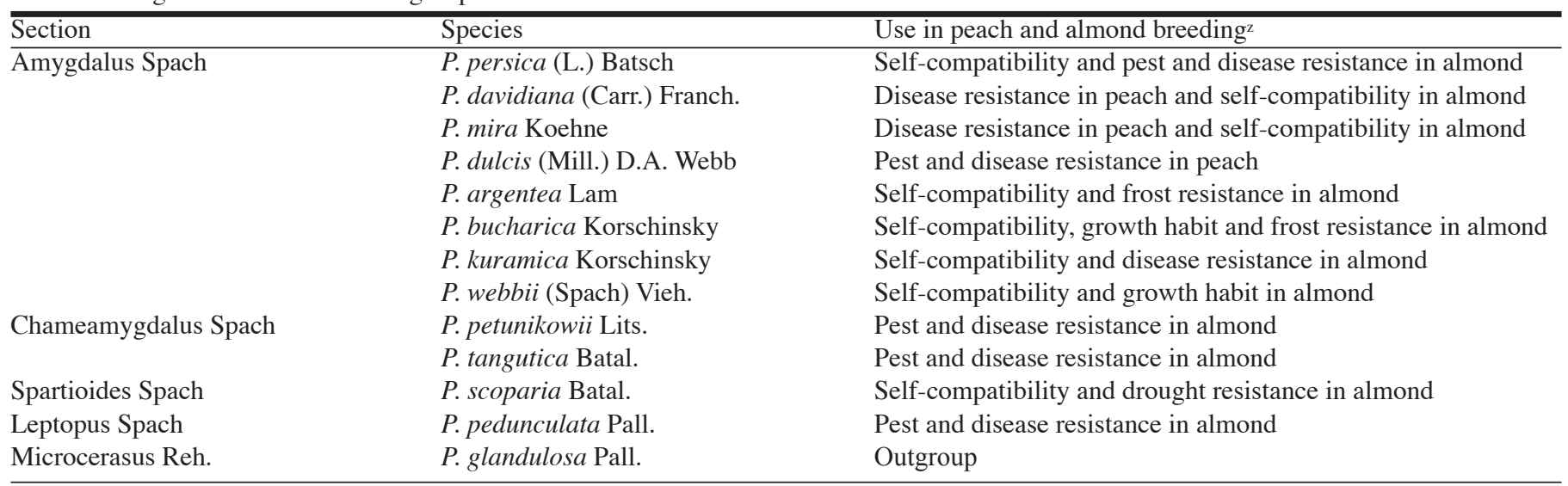

zDenisov, 1988; Gradziel et al., 2001; Grasselly, 1976; Hesse, 1975; Kester et al, 1991; Kester and Gradziel, 1996; Scorza and Sherman, 1996. 
Table 3. SSR markers assayed and polymorphism observed among the peach, almond and related Prunus species assayed.

\begin{tabular}{llccc}
\hline & & \multicolumn{2}{c}{ Polymorphism } & Rize range \\
\cline { 2 - 4 } Marker & Origin & Alleles (no.) & $195-212$ & Sosinski et al., 2000 \\
\hline PS08E08 & Cherry & 6 & $178-218$ & Sosinski et al., 2000 \\
PS12A02 & Cherry & 5 & $80-154$ & Cipriani et al., 1999 \\
UDP96-001 & Peach & 9 & $50-180$ & Cipriani et al., 1999 \\
UDP96-003 & Peach & 10 & $110-210$ & Cipriani et al., 1999 \\
UDP96-005 & Peach & 9 & $120-170$ & Cipriani et al. 1999 \\
UDP96-008 & Peach & 6 & --- & Cipriani et al., 1999 \\
UDP96-010 & Peach & 0 & $130-245$ & Cipriani et al., 1999 \\
UDP96-013 & Peach & 8 & --- & Cipriani et al., 1999 \\
UDP96-015 & Peach & 0 & $220-260$ & Cipriani et al. 1999 \\
UDP96-018 & Peach & 9 & $205-245$ & Cipriani et al., 1999 \\
UDP96-019 & Peach & 7 & $92-160$ & Cipriani et al., 1999 \\
UDP97-401 & Peach & 6 & 134 & Cipriani et al., 1999 \\
UDP97-402 & Peach & 1 & $120-170$ & Cipriani et al., 1999 \\
UDP97-403 & Peach & 8 & $82-150$ & Cipriani et al., 1999 \\
UDP98-405 & Peach & 9 & $73-140$ & Cipriani et al., 1999 \\
UDP98-406 & Peach & 6 & $178-220$ & Cipriani et al., 1999 \\
UDP98-407 & Peach & 6 & $73-207$ & Cipriani et al. 1999 \\
UDP98-408 & Peach & 9 &
\end{tabular}

analysis, are shown as an unrooted NJ dendrogram in Fig. 1. Four main groups were observed. Group 1 included Prunus persica cultivars and accessions of $P$. davidiana and $P$. mira; Group 2 contained the $P$. dulcis cultivars; Group 3 included accessions of $P$. argentea, $P$. bucharica, $P$. kuramica, $P$. pedunculata, $P$. petunnikowii, P. tangutica, and P. webbii; and Prunus glandulosa and P. scoparia formed Group 4.

Figure 1 resulted from an analysis in which 0's were assigned to all alleles in a particular accession for any marker for which no amplification was observed in that accession. There was a total of 384 such cells in our data matrix, $17.1 \%$ of the total $(2244$ cells). When those cells were instead coded with missing values (?) (results not shown), the four groups described above were again recovered, but the relationships among them were slightly different. Thus, while in Fig. 1 the almond cultivars (Group 2) clustered with Group 3, in the alternate analysis Group 2 clustered with P. glandulosa and P. scoparia (Group4). The branching order within Group 3 was also slightly different in the two analyses.

\section{Discussion}

Amplification was successful in peach for all markers initially developed in peach. These results agree with reports by Cipriani et al. (1999) of the successful use of these markers. Results showed a high degree of homology for the SSR loci between peach and almond. Of 18 markers with successful amplification in peach, 15 also showed successful amplification in almond (Table 2). These results support a close evolutionary distance between these species as suggested by Watkins (1976).

The level of polymorphism in our peach cultivars was similar to that reported by Cipriani et al. (1999). The range of the amplified band sizes in peach, almond and Prunus species (Table 2) was also similar to those reported by Downey and Iezzoni (2000) for black cherry and Cipriani et al. (1999) for peach using the same primer pairs.

Variations in the number of polymorphic SSR marker and the total number of polymorphism (detected alleles) were observed (Table 4), allowing differentiation into two groups, one with a high number of polymorphic bands (higher than 20) (P. argentea, P. bucharica, P. davidiana, P. kuramica, P. mira, and P. webbii), and a second group with a much reduced number of polymorphic bands (between 10 to 13) (P. glandulosa, P. pedunculata, P. petunikowii, $P$. scoparia, and $P$. tangutica). The small sample per species, however, does not allow broader generalizations about the species in general.

Differences in amplification success for SSR markers observed among species are due to the genetic variability between the different species and peach, where the SSRs were developed. A decrease in the amount of polymorphic SSR markers would be expected as genetic distance increases from the designated anchor species.

Results also demonstrated the possibility of cross-species transfer for several SSR markers and consequently the value of markers developed in one species of Prunus for the characterization of other species within the subgenus. Results may have value in assessing cross-species genetic compatibility and could be useful

Table 4. SSR markers assayed and polymorphism observed for the Prunus species evaluated.

\begin{tabular}{|c|c|c|c|c|}
\hline Species & $\begin{array}{c}\text { SSR } \\
\text { assayed }^{2} \\
\text { (no.) }\end{array}$ & $\begin{array}{c}\text { SSRs } \\
\text { amplifiedy } \\
\text { (no.) }\end{array}$ & $\begin{array}{c}\text { Polymorphic } \\
\text { SSRs }^{\mathrm{x}} \\
\text { (no.) }\end{array}$ & $\begin{array}{c}\text { Total } \\
\text { alleles } \\
\text { detected }^{\mathrm{w}} \\
\text { (no.) }\end{array}$ \\
\hline P. argentea & 18 & 13 & 6 & 21 \\
\hline P. bucharica & 18 & 12 & 8 & 26 \\
\hline P. davidiana & 18 & 16 & 6 & 24 \\
\hline P. dulcis & 18 & 15 & 15 & 48 \\
\hline P. glandulosa & 18 & 6 & 4 & 10 \\
\hline P. kuramica & 18 & 13 & 6 & 22 \\
\hline P. mira & 18 & 15 & 8 & 24 \\
\hline P. pedunculata & 18 & 11 & 4 & 16 \\
\hline$P$. persica & 18 & 18 & 17 & 42 \\
\hline P. petunikowii & 18 & 7 & 3 & 11 \\
\hline P. scoparia & 18 & 10 & 2 & 13 \\
\hline P. tangutica & 18 & 10 & 4 & 14 \\
\hline P. webbii & 18 & 15 & 9 & 25 \\
\hline
\end{tabular}

zNumber of SSR markers screened.

yNumber of SSR that amplified.

${ }^{x}$ Number of polymorphic loci detected by marker.

wTotal number of alleles detected. 


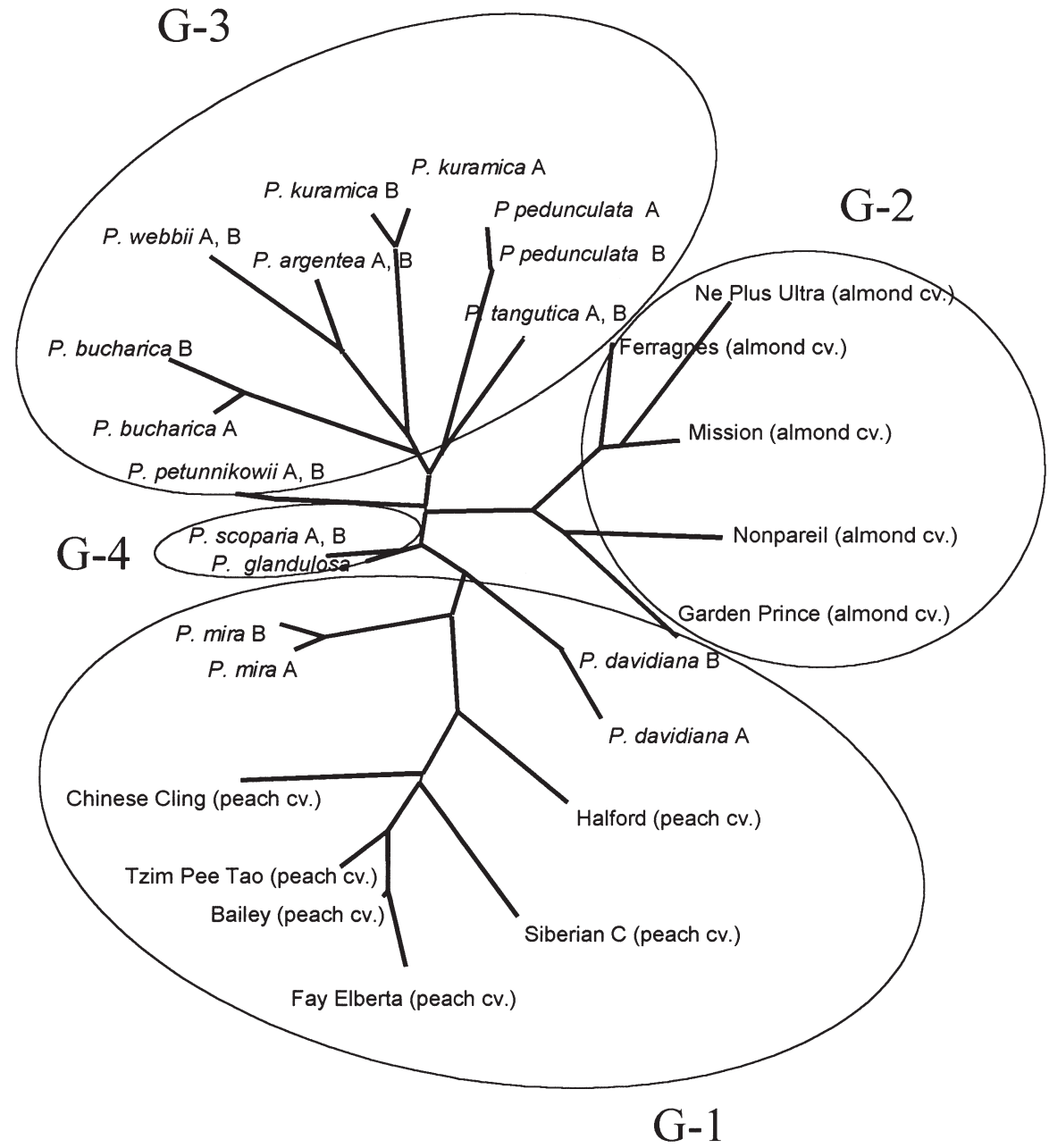

- 0.01 changes

Fig. 1. Unrooted dendogram obtained by neighbor-joining cluster analysis based on the mean character difference distances among the different species. Prunus glandulosa was included as an outgroup.

for developing a consensus linkage map for Prunus as well as in studies assaying the gene pool value (Downey and Iezzoni, 2000; Joobeur et al., 2000; Westman and Kresovich, 1997).

Prunus davidiana and P. mira are shown to be closer to peach than to almond as proposed by Hesse (1975) and Scorza and Sherman (1996). Successful hybridization between $P$. dulcis (almond) and $P$. argentea, $P$. bucharica, $P$. kuramica, and $P$. webbii has been also reported by different authors (Kester et al., 1991; Kester and Gradziel, 1996).

The phenetic relationships inferred among the peach and almond cultivars and related species studied here are in general agreement with previous taxonomic and phylogenetic studies. All of the species except $P$. glandulos $a$ were classified by Rehder (1940) in section Amygdalus of subgenus Amygdalus. We recovered four major clusters: one including the peach cultivars plus $P$. davidiana and P. mira, a second including the almond cultivars, a third including all of the remaining species studied except $P$. scoparia and $P$. glandulosa, which formed the fourth group. The first group includes the fleshy-fruited species commonly referred to as peaches and the second and third groups include dry-fruited species known as almonds. The results of a phylogenetic study of chloroplast and nuclear DNA sequence data (Bortiri et al., 2001), which included some but not all of the species studied here, supported a sister relationship between $P$. persica and $P$. davidiana and a close relationship between those species and $P$. dulcis, $P$. bucharica and $P$. argentea. Mowrey and Werner (1990) and Badenes and Parfitt (1995) also indicated a similar grouping of peach with P. davidiana and P. mira.

The relative positions of the four clusters varied depending on how we coded alleles for markers for which no amplification was observed in some accessions. The second and third groups (cultivated and wild almonds) clustered together in one analysis but not the other, in which cultivated almonds clustered with P. scoparia and P. glandulosa. The variation in the position of group 4 , including the last two taxa, probably stems from the fact that they had the highest proportion of markers for which no amplification was observed.

The genetic similarity observed between $P$. glandulosa and P. scoparia was surprising. While the latter species is considered a close relative to $P$. dulcis, the former was classified in section Microcerasus of subgenus Cerasus (Rehder, 1940), though the results of Bortiri et al. (2001) suggest that members of this section are actually closely related to members of subgenus Prunus.

Prunus bucharica and P. kuramica have been described as the Prunus species more closely related to almond (Browick and Zohary, 1996; Grasselly, 1976), and are also described as ancestral species of the modern cultivated almond by Kester et al. (1991). More recently, however, Browicz and Zohary (1996) proposed only P. fenzliana as the wild ancestor of almond. Unfortunately, $P$. fenzliana germplasm was not available for this study.

Natural introgression of genes from related Prunus species to almond has been reported (see review by Kester et al., 1991). Kester and Gradziel (1996) suggest that the sweet kernel trait, in addition to being a natural variant within $P$. dulcis, may have been independently transferred to $P$. dulcis from $P$. bucharica or P. kuramica. Prunus webbii may also be the original source of self-compatibility in European almond cultivars including 'Genco', 'Tuono' or 'Cristomorto' with natural introgression of this gene occurring during the centuries of almond cultivation in the Puglia region of Italy (Reina et al., 1985).

\section{Conclusions}

Both peach and almond suffer from a limited gene pool available for future breeding progress. Interspecific gene transfer among these Prunus species offers a greatly expanded genetic diversity available to breeders, particularly given the relative ease of the initial hybridization and subsequent backcrosses (Gradziel et al., 2001). Further SSR analysis of this germplasm offers opportunities for determining more precise genetic relationships and could be an important tool for marker assisted gene transfer. DNA fingerprinting using SSR analysis could also be very useful for the early selection of the most promising progeny from interspecific crosses or backcrosses, leading to greatly improved breeding efficiency. 


\section{Literature Cited}

Aranzana, M.J., J. García-Mas, J. Carbó, and P. Arús. 2002. Development and variability analysis of microsatellite markers in peach. Plant Breeding 121:87-92.

Badenes, M.L. and D.E. Parfitt. 1995. Phylogenetic relationships of cultivated Prunus species from an analysis of chloroplast DNA variation. Theor. Appl. Genet. 90:1035-1041.

Bernhard, R. 1949. The peach-almond and its utilization. Revue Horticole 121:97-101

Bortiri, P.E., S. Oh, J. Jiang, S. Baggett, A. Granger, C. Weeks, D. Potter, and D.E. Parfitt. 2001. Phylogeny and systematics of Prunus (Rosaceae) as determined by sequence analysis of ITS and the chloroplast trnL-trnF spacer DNA. Systematic Bot. 26:797-807.

Brooks, R.M. and H. Olmo. 1982. Register of new fruit and nut varieties List-32. HortScience 17:17-23.

Browicz, K. and D. Zohary. 1996. The genus Amygdalus L. (Rosaceae): Species relationships, distribution and evolution under domestication. Genet. Resour. Crop Evol. 43:229-247.

Cantini, C., A.F. Iezzoni, W.F. Lamboy, M. Boritzki, and D. Struss. 2001. DNA fingerprinting of tetraploid cherry germplasm using simple sequence repeats. J. Amer. Soc. Hort. Sci. 126:205-209.

Cipriani, G., G. Lot, H.G. Huang, M.T. Marrazzo, E. Peterlunger, and R. Testolin. 1999. AC/GT and AG/CT microsatellite repeats in peach (Prunus persica (L) Basch): Isolation, characterization and cross-species amplification in Prunus. Theor. Appl. Genet. 99:65-72.

Denisov, V.P. 1988. Almond genetic resources in the USSR and their use in production and breeding. Acta Hort. 224:299-306.

Dirlewanger, E., A. Crosson, P. Tavaud, M.J. Aranzana, C. Poizat, A. Zanetto, P. Arús, and L. Laigret. 2002. Development of microstellite markers in peach and their use in genetic diversity analysis in peach and sweet cherry. Theor. Appl. Genet. 105:127-138.

Downey, L.D. and A.F. Iezzoni. 2000. Polymorphic DNA markers in black cherry are identified using sequences from sweet cherry, peach, and sour cherry. J. Amer. Soc. Hort. Sci. 125:76-80.

Faust, M. and B. Timon. 1995. Origin and dissemination of peach, p. 1-33. In: J. Janick (ed.). Horticultural reviews. vol 17. Wiley, New York.

Gepts, P. and M. Clegg. 1989. Genetic diversity in pearl millet (Penisetum glaucum) at the DNA sequence level. J. Hered. 80:302-208.

Gradziel, T.M. and D.E. Kester. 1998. Breeding for self-fertility in California almond cultivars. Acta Hort. 470:109-117.

Gradziel, T.M., P. Martínez-Gómez, F. Dicenta, and D.E. Kester. 2001. The utilization of Prunus species for almond variety improvement. J. Amer. Pomol. Soc. 55:100-108.

Grasselly, C. 1976. Les espèces sauvages d'amandier (in French). Options Méditerr. 32:28-44.

Gupta, P.K., H.S. Balyan, P.C. Sharma, and B. Ramesh. 1996. Microsatellites in plants: A new class of molecular markers. Curr. Sci. 70: $45-54$.
Hesse, C. O. 1975. Peaches, p. 285-326.. In: J. Janick and J.N. Moore (eds.). Advances in fruit breeding. Purdue Univ. Press, West Lafayette, Ind.

Joobeur, T., N. Periam, M.C. de Vicente, G.J. King, and P. Arús. 2000. Development of a second generation linkage map for almond using RAPD and SSR markers. Genome 43:649-655.

Kester,D.E. and C.J. Hansen. 1966. Rootstock potentialities of F1 hybrids between peach (Prunus persica L.) and almond (Prunus amygdalus Batsch.). J. Amer. Soc. Hort. Sci. 89:100-109.

Kester,D.E., T.M. Gradziel, and C. Grasselly. 1991.Almonds (Prunus), p. 701-758. In: J.N. Moore and H.J. Ballington (eds.). Genetic resources of temperate fruit and nut crops. Intl. Soc. Hort. Sci., The Netherlands.

Kester, D.E. and T.M. Gradziel. 1996. Almonds, p. 1-97. In: J. Janick and J.N. Moore (eds.). Fruit breeding. Wiley, New York.

Lee, S. and J. Wen. 2001. A phylogenetic analysis of Prunus and the Amygdaloideae (Rosaceae) using ITS sequences of nuclear ribosomal DNA. Amer. J. Bot. 88:150-1160.

Mowrey, B.D. and D.J. Werner. 1990. Phylogenetic relationships among species of Prunus as inferred by isoenzyme markers. Theor. Appl. Genet. 80:129-133.

Rehder, A. 1940. Manual of cultivated trees and shrubs hardy in North America. Macmillan, New York.

Reina, A., V. Giorgio, and A. Godini. 1985. Autres types autocompatibles parmi la population d'amandiers des Pouilles (in Italian). Options Méditerr. 85:25-29.

Saitou, N. and M. Nei. 1987. The neighbor-joining method: a new method for reconstructing phylogenetic trees. Mol. Biol. Evol. 4:406-425.

Scorza, R. and W.B. Sherman. 1996. Peaches, p. 285-326. In: J. Janick and J.N. Moore (eds.). Fruit breeding. Wiley, New York.

Sosinski, B., M. Gannavarapu, L.E., Hager, L.E. Beck, G.J. King, C.D. Ryder, S. Rajapakse, W.V. Baird, R.E. Ballard, and A.G. Abbott. 2000. Characterization of microsatellite markers in peach (Prunus persica (L) Basch). Theor. Appl. Genet. 101:421-428.

Swofford, D.L. 2000. PAUP* phylogenetic analysis using parsimony (* and other methods). version 4. Sinauer Associates, Inc., Sunderlan.

Uematsu, C., T. Sasakumand, and Y. Ogihara. 1991. Phylogenetic relationships in stone-fruit group of Prunus revealed by restriction fragment analysis of chloroplast DNA. Jpn. J. Genet. 66:59-69.

Wang, Y., L.L. Georgi, N. Zhebentyayeva, G.L. Reighard, R. Scorza, and A.G. Abbott. 2002. High throughput targeted SSR marker development in peach (Prunus persica). Genome 45:319-328.

Watkins, R. 1976. Chery, plum, peach, apricot and almond, p. 342-347. In: N.W. Simmonds (ed.). Evolution of crop plants. Longman, London.

Westman, A.L. and S. Kresovich. 1997. Use of molecular marker techniques for description of plant genetic variation, p. 9-48. In: J.A. Callow, F. Ford-Lloyd, and H.J. Newbury (eds.). Biotechnology and plant genetic resources. CAB Intl., New York. 